\title{
VOKIEČIŲ EVAKUACIJA IŠ LIETUVOS 1919 M. ITALIJOS TARPSĄUUNGINĖS KOMISIJOS NARIO AKIMIS: 1919 M. SPALIS-GRUODIS
}

\author{
Dr. Ciro Paoletti
}

Kaip gerai žinoma, 1919 m. rudenị vokiečiai vis dar buvo Lietuvoje ir Latvijoje. Baltijos bajorai, trokštantys išlaikyti savo turtą, palaikė vokiečius, kurie vis dar tikejosi aneksijos.

Teoriškai vokiečiai skelbè norintys padèti Latvijai ir Lietuvai atsilaikyti prieš komunistus, tačiau faktiškai tiesiog ieškojo rimtos priežasties pasiaiškinti Sajungininkams, kodèl jie vis dar čia. Latvijoje ir Lietuvoje veikè trys skirtingos užsienio karinès organizacijos: Vokietijos armija Reichswher, - kuri atsisakè išvykti, Nikolajaus Judeničiaus vadovaujami Rusijos baltagvardiečiai ir jungtinè Vokietijos ir Rusijos kariuomenè, kuriai įsakinejo Pavelas Bermontas-Avalovas. Tiek Latvijos, tiek Lietuvos vyriausybès buvo „istrigusios“ tarp Rusijos komunistų ir vokiečių.

Paryžiuje Sąungininkai stebejjo situaciją, tačiau ir jie buvo susiskaldę. JAV ir Italija neturejjo politinių interesų Baltijos regione, o Prancūzija ir Didžioji Britanija buvo juo susidomejusi. Britai labiausiai sieke kovoti su komunistais ir dèl kiekvienos Baltijos valstybès visiškos nepriklausomybès. Prancūzai norèjo rezultatų, palankių savo užsienio politikai. Nuo XVI a. antros pusès, remdami Lenkiją, jie siekè sukelti kuo daugiau rūpesčių Vokietijai ir Habsburgų dinastijai. Kai šis klausimas vèl iškilo, Baltijos regionas tapo jiems įdomus. Prancūzija skatino sudaryti Baltijos valstybių konfederaciją, ị ją ịtraukiant Suomiją ir galbūt net Lenkijąa. Ji spaudè remti Baltijos šalių nepriklausomybę, pasiūlè ịsteigti specialią komisiją, grindè savo užmačias realiais grasinimais okupuoti Rūro ir Reino kraštą.

Nepaisant skirtingų valstybių sąjungininkių nuomonių, visas jaudino

Tuo metu sąvoka „Baltijos valstybès“ apèmė Latviją, Estiją, Lietuvą, Suomiją ir Lenkiją, t. y. visas buvusias Rusijos teritorijas prie Baltijos jūros. 
pagrindinè problema - vokiečiu kariai ir savanoriai, kurie liko Baltijos šalyse, nes bolševikai nebekèlè tiesioginès grèsmès, tad esminis klausimas buvo, kaip priversti vokiečius palikti ši kraštą.

Nuo spalio pradžios Sąjungininkai spaudè vokiečius, kad jie atsisakytų neseniai susikūrusių nepriklausomų Baltijos valstybių. 1919 m. spalio 4 d. Vokietijos vyriausybè paskelbẻ norinti padaryti viską, ką gali, kad Vokietijos kariai paliktų šią teritoriją².

Matydama, kad niekas nevyksta, spalio $10 \mathrm{~d}$. Sajungininku pajègų Aukščiausioji taryba ịkūrẻ Komisiją vokiečių evakuacijos iš Baltijos šalių, daugiausia Latvijos ir Lietuvos, klausimui spręsti ${ }^{3}$.

Vietos situacija buvo neaiški. Nebuvo informacijos „iš pirmų rankų“. Sajungininkus pasiekè vos kelios naujienos, ir tos pačios - per Vokietijos arba Švedijos spaudą. Vienintele tiksli žinia - situacija bloga, bet neaišku, kiek vyrų sudaro Baltijos regione dislokuotus vokiečių, rusų ir mišrius vokiečiu ir rusų karinius dalinius 4 .

Spalio 22 d. Prancūzijos generolas Dupontas (Dupont) iš Berlyno rašè, jog Vokietijos karo ministras Gustavas Noske (Gustav Noske) pripažino, kad apie 40000 vokiečių (15 000 - Mintaujos (dabar Jelgava - mokslinis redaktorius) mieste su generolu fon der Golcu (von der Goltz) ir 25000 - su Rusijos generolu Bermontu) atsisako palikti Baltijos šalis ir kad jis - Noske rengiasi priversti juos iš ten pasitraukti visiškai nutraukus anglių tiekimą

2 Archivio dell' Ufficio storico dello Stato Maggiore dell' Eserecito (AUSSME), Fondo E 8 - Registro Commissione Interalleata di Parigi, Raccoglitore n. 98 - Stati Baltici, busta 7 Il generale Niessel - Commissione interalleata delle provincie baltiche - 1919-1921; sottofascicolo 7 - Stati baltici e commissione interalleata - varie - note by mr. Wachendorf on October 4th, 1919, given Marshall Foch on October $5^{\text {th }}, 1919$ - French translation, copy.

3 AUSSME, Fondo E 8 - Registro Commissione Interalleata di Parigi, Raccoglitore n. 98 - Stati Baltici, busta 4, Il generale Niessel - Commissione interalleata delle provincie baltiche - 1919-1921; Instructions pour le général Niessel.

4 AUSSME, Fondo E 8 - Registro Commissione Interalleata di Parigi, Raccoglitore n. 98 - Stati Baltici, busta 7 Il generale Niessel - Commissione interalleata delle provincie baltiche - 1919-1921; sottofascicolo 7 - stati baltici e commissione interalleata - varie Delegazione italiana per la pace - sezione militare, telegramma da MMIG Berlino a ministro esteri e delegazione italiana pace sez militare Parigi, 20 ottobre 1919.

5 AUSSME, Fondo E 8 - Registro Commissione Interalleata di Parigi, Raccoglitore n. 98 - Stati Baltici, busta 7 Il generale Niessel - Commissione interalleata delle provincie baltiche - 1919-1921; sottofascicolo 7 - stati baltici e commissione interalleata - varie Segretariato italiano della conferenza, 21 ottobre 1919. 
Spalio 28 d. Sąjungininkų pajègų Aukščiausioji taryba išnagrinèjo Komisijos Vokietijos evakuacijai iš Baltijos provincijų prižiūrèti steigimo projektą ${ }^{6}$. Kitą dieną Italijos delegacija Paryžiuje praneše Romai, kad kiekviena valstybè turi mokèti savo personalui, dirbančiam naujai įsteigtoje Evakuacijos komisijoje, ir pasiūlè riboti Italijos dalyvavimą joje, paliekant tik ,generolą Marietị (Marietti), vieninteli pareigūną, rašomąją mašinèlę,

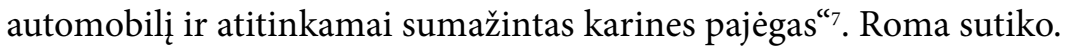

Spalio 31 d. Sąjungininkų pajègų Aukščiausioji taryba leido Komisijai naudotis Sąjungininkų karinių misijų personalu Baltijos šalyse ${ }^{8}$. Tuomet buvo pateiktos jos sudeties ir pareigų instrukcijos, tiesa, labai trumpos. Komisijos prezidentas - Prancūzijos generolas H. A. Niselis (Niessel), nariai: D. Britanijos generolas $\mathrm{H}$. Turneris (Turner), Amerikos brigados generolas S. A. Čenis (Cheney), Italijos brigados generolas Marietis ir Japonijos pèstininkų vadas G. Takeda.

Komisija turèjo kontroliuoti visų vokiečių karių ir vokiečių tautybės civilių evakuaciją iš Baltijos šalių. Galèjo likti tik tie asmenys, kuriuos Baltijos vyriausybès palankiai prièmè. Viskas turèjo būti atlikta derinant veiksmus ir bendradarbiaujant su visų trijų Baltijos šalių vyriausybėmis. Vokietijos vyriausybe turèjo įsakyti savo kariuomenei paklusti ir paskirti kelis delegatus dirbti kartu su Komisija, vadovaujantis jos nurodymais?.

6 AUSSME, Fondo E 8 - Registro Commissione Interalleata di Parigi, Raccoglitore n. 98 - Stati Baltici, busta 4 Il generale Niessel - Commissione interalleata delle provincie baltiche -1919-1921; Risoluzione presa dal Consiglio Supremo degli Alleati nella seduta del 28 ottobre 1919 - H. D. 77 (i).

7 AUSSME, Fondo E 8 - Registro Commissione Interalleata di Parigi, Raccoglitore n. 98 - Stati Baltici, busta 7 Il generale Niessel - Commissione interalleata delle provincie baltiche - 1919-1921; sottofascicolo 7 - stati baltici e commissione interalleata - varie Delegazione italiana per la pace - sezione militare, Telegramma da Parigi del 29 ottobre 1919 al ministero della guerra divisione SM e per conoscenza a Comando Supremo Reparto Operazioni. Faktiškai Italijos delegaciją sudare generolas Marietis, pirmasis leitenantas Fermas Reverberis (Fermo Reverberi), keturi eiliniai ir karabinierius.

8 AUSSME, Fondo E 8 - Registro Commissione Interalleata di Parigi, Raccoglitore n. 98 - Stati Baltici, busta 4, Il generale Niessel - Commissione interalleata delle provincie baltiche - 1919-1921; Risoluzione presa dal Consiglio Supremo degli Alleati nella seduta del 30 ottobre 1919 - H. D. 79 (IV).

9 AUSSME, Fondo E 8 - Registro Commissione Interalleata di Parigi, Raccoglitore n. 98 - Stati Baltici, busta 4, Il generale Niessel - Commissione interalleata delle provincie baltiche - 1919-1921; risoluzione presa dal Consiglio Supremo degli Alleati nella seduta del 5 novembre 1919 - H. D. 84 (IV). 
Tą pačią dieną vokiečiai ir lietuviai sutarè, kad geležinkelis Schawli-Tauroggen (Šiauliai-Tauragè) bus laikomas neutralia zona, naudojama Vokietijos kariuomenès evakuacijai vykdyti.

1919 m. lapkričio 1 d. tarpsajunginė Aukščiausioji taryba nurodė Vokietijos vyriausybei evakuotis iš Baltijos provincijų ir priimti Komisiją kaip vienintelị vykdomąjị ir kontroliuojantị organą.

Prieš išvykdama iš Paryžiaus, lapkričio $3 \mathrm{~d}$. Komisija pirmąkart susitiko su keliais Baltijos šalių atstovais. Jie pasidalijo patikima informacija iš „pirmų rankų "10. Atstovai informavo, kad karo metu vokiečiai pakeitė geležinkelio standartą iš rusiško ị europietišką. Jie tikejjosi, kad vokiečiai paliks geležinkelio statybai tiek medžiagų, kiek rado šioje teritorijoje prieš karą, taip pat viską, kas reikalinga geležinkelio eismui valdyti.

Komisija pareiškè, kad Vokietijos kariuomenè turi būti atskirta nuo Rusijos baltagvardiečių, o iš Baltijos valstybių teritorijoje esančių žemès savininkų žemès perimtos, jiems sąžiningai už jas sumokèjus.

Komisijai buvo pranešta, kad Vokietijoje veikè net 16 naujokų prièmimo punktų, kurie siuntė karius savanorius ị Baltijos šalis. Kitą dieną generolas Niselis paskelbe், kad Vokietijos vyriausybè laikoma atsakinga tiek už Vokietijos, tiek už Vokietijos ir Rusijos, tiek už Rusijos kariuomenes. Lapkričio $7 \mathrm{~d}$. Komisija iš Paryžiaus išvyko ị Berlyną.

Po pirmojo susitikimo su vokiečiais paaiškejo du skirtingi Vokietijos požiūriai. Vokietijos karo ministras G. Noskè, pasirodè, šiuos sprendimus palaike ir buvo pasirengęs bendradarbiauti. Akivaizdu, jis labai gerai suprato visas grèsmes Vokietijai, sukèlus Sąungininkų nepasitenkinimą. Be to, spaudoje sklandè gandai apie prancūzų invaziją i Rūro ir Reino kraštą, o tai jau būtų papildomas spaudimas Vokietijos vyriausybei spręsti Baltijos šalių problemą. Deja, G. Noskès nepalaikè jo personalas. Jis įsakinèjo, tačiau nebuvo užtikrintas, kad šie issakymai vykdomi, arba jie buvo vykdomi per lètai. Kita vertus, po pirmojo susitikimo tapo aišku, kad tiek karinių, tiek diplomatinių korpusų pareigūnai norèjo laimèti kuo daugiau laiko iki Taikos sutarties sudarymo ir kuo ilgiau išlaikyti

10 AUSSME, Fondo E 8 - Registro Commissione Interalleata di Parigi, Raccoglitore n. 99 - Stati Baltici, Commissione interalleata - diario della delegazione italiana - novembre 1919 - novembre 1920. 
Baltijos teritoriją. Po susitikimo su admirolu Hopmanu (Hopmann $)^{11}$, kuris vèliau tapo vyriausiuoju Vokietijos ryšiu su Komisija palaikymo pareigūnu, H. N. Niselis sausai apibūdino jo pastangas švelninti situaciją: vokiečiams „reikia tik ìsakymu, kuriems jie paklustu, ir instrukcijų, kurias jie gautų“.

Komisija nusprende, kad Vokietijos generolas V. Eberhardtas (Eberhardt) turi likti Baltijos šalyse iki vokiečių pasitraukimo pabaigos, ir paprašè Prancūzijos ir Didžiosios Britanijos misijų Baltijos šalyse padèti išsiųsti visus šios tautybės civilius, išskyrus palankiai priimtus asmenis ir asmenis, dirbančius geležinkelyje.

Karinè padètis, su kuria susidūre Komisija, buvo išties neaiški. Anot Hopmano, Baltijos šalyse vokiečiai turèjo 120 baterijų, $20150 \mathrm{~mm}$ pabūklų, 120 lèktuvų, tačiau jiems trūko drabužių ir pinigų. Pasak Lietuvos vyriausybès, $1919 \mathrm{~m}$. spalio viduryje vokiečiai turejjo 54000 vyrų, neskaitant tarnaujančiųjų fon der Golco vadovaujamuose Vokietijos armijos V ir VI korpusuose ${ }^{12}$.

${ }^{11}$ Lapkričio 9 d. admirolas Hopmanas pasakojo Niseliui, kad vokiečiu kariai tikèjo, jog yra dislokuoti Baltijos šalyse kovoti su komunistais, kaip kad norẻjo Sajungininkai. Jis pridūré, kad kareiviai bijo dèl vietinių vokiečių gyvybès, jei jiems tektų išvykti iš šios teritorijos. Be to, prasitare, jog nežino tikrosios karinès padèties, minèdamas, kad teritorijoje, „atrodo, yra Geležine divizija, Plehwe grupe, savanoriu korpusas ir Vokietijos legionas“. Kalbėdamas apie Vokietijos generolus, Hopmanas pritarė Niseliui, kad Eberhardtas yra visiškai atsakingas už vokiečius, bet jis buvo siųstas ten skubiai perimti fon der Golco pareigų, tik tada suprato, kad dauguma vokiečių perėjo į Rusijos baltagvardiečių pusę. Hopmanas sakè, kad ten yra ne tiek jau daug karinių išteklių, kad Vokietijos vyriausybè uždarẻ kariu naujokų ėmimo biurus. Jis pabrèžè, kad Rytprūsiuose netelkiama didelè jèga ir pasitraukimas jūrų keliais nèra gera idèja, nes dèl laivų stokos ir ịtempto anglies bei maisto gabenimo laivais grafiko būtų buvę galima perkelti tik po 1000 vyrų kas trečią dieną. Lapkričio $11 \mathrm{~d}$. Hopmanas bandè dar kartą kliudyti sakydamas, kad idejja kurti Sąjungininkų prižiūrimus kontrolès punktus Vokietijoje nèra gera ir kad nè viena paliaubų taisyklè nenumato Vokietijos agentų išsiuntimo iš Baltijos šalių. Galiausiai jis bandè gauti leidimą Vokietijos kariuomenei prisijungti prie Judeničiaus.

12 AUSSME, Fondo E 8 - Registro Commissione Interalleata di Parigi, Raccoglitore n. 99 - Stati Baltici, Commissione interalleata - diario della delegazione italiana - novembre 1919 - novembre 1920; allegato n. 8, "Situazione delle forze nei Paesi baltici alla seconda metà di ottobre 1919 (approssimata)”. Skiltyje „Pagal informaciją iš Lietuvos šaltiniụ" teigiama: 15000 vyrų buvo Geležinëje divizijoje, 12000 - Sargybos rezervų divizijoje, 3000 - II pestininkų brigadoje, 3000 - Piebitscho korpuse, 9000 - Vyrgolitcho korpuse, 12000 - Bermonto kariuomenèje. Estijos šaltiniuose nurodomi tik 47000 vyrų, ịskaitant 12000 vyrų VI rezervų korpuse, 7000 - V korpuse, 1000 - Mituvos sargyboje, tačiau 
Generolas V. Eberhardtas paaiškino, kad Rusijos ir Vokietijos pajègas sudaro 49000 vokiečių, 10000 rusų ir 5 000-10 000 latvių, 150 lengvųjų pabūklų, 50-60 sunkiųjų pabūklų, 40-50 karo aviacijos vienetų (daugiausia jų buvo dislokuota prie Rygos). Lapkričio $11 \mathrm{~d}$. 15000 vokiečių pasitraukè iš Baltijos šalių, paskui juos išvyko dar 5000 ar 6000 vyrų, netarnaujančių reguliariosios kariuomenès daliniuose. Jis pridūrè, kad Bermontui nelabai patiko idejja užimti poziciją vokiečių naudai, bet tai padaryti ji privertė Baltijos baronai.

Visi kariai galejo išvykti geležinkeliu. Buvo 110 garvežių ir apie 1000 vagonų. Geležinkelio tinklas buvo platesnis nei 1914 m., nes vokiečiai per pastaruosius penkerius metus nutiesė daug bėgių.

Komisija vèl susitiko su Baltijos šalių atstovais. Niselis kalbejo apie susiklosčiusią situaciją, naujųjų vyriausybių ir Baltijos baronų santykius. Jis sakè, kad būtina nuosaikių pažiūrų politika, kad jų labai nesuerzintų, nes jų interesai - pagrindinè priežastis, laikanti vokiečius šioje teritorijoje. Lietuvos atstovas atsakè, kad Lietuva jau bande vykdyti tokią politiką, deja, nesèkmingai, sèkmè taip pat nelydèjo ir vokiečių pareigūnus mėginant išvaryti iš šalies. Niselis minèjo „davęs jiems pasus“, kas netiesiogiai reiškè: „Jus dabar remia Sajungininkai. “Latviai pripažino, kad jų vyriausybė neketina dalyti žemès valstiečiams, bet, to nepaisydami, vietiniai baronai be jos leidimo apgyvendino vokiečių darbininkus savo žemėse, ir ne atsitiktine tvarka, o strategiškai svarbiose zonose, ir davej jiems ị rankas ginklus.

Lietuvos atstovas prakalbo, kad jo šalyje nèra vokiečių žemvaldžių, tik lenkų žemvaldžiai.

Galiausiai abu - tiek Latvijos, tiek Lietuvos - atstovai pranešè Evakuacijos komisijai, kad, vokiečiams pasitraukus, jie galètų saugiai perimti geležinkelių sistemos valdymą su visa administracija, ir nesijaudina dèl komunistų, nes, vokiečiams išvykus, abi vyriausybės galètų sutelkti savo karines pajègas krašto apsaugai ir sienų kontrolei užtikrinti.

Lapkričio 12 d. Komisija pasiekè Karaliaučių (Königsberg), susitiko su vietos Vokietijos valdžia ir pradèjo savo darbą. Prūsijos Vokietijos pareigūnai bandè stabdyti evakuaciją, teigdami, kad iš Baltijos regiono pasitraukiantys kariai kartu išsivestų daugiau nei 130 000, galbūt net 150000

nepateikta Sargybos rezervų divizijos ir Piebitscho korpuso karių skaičiaus, be to, priskirta tik 8000 vyrų Geležinei divizijai, 4000 - Vyrgolitchui ir 9000 - Bermontui, tačiau suskaičiuota net 6000 vyrų II pèstininkų brigadoje. 
civilių, tad Prūsijos valdžiai reikia daugiau laiko jų apgyvendinimui organizuoti. Niselis šaltai atrěžè, kad Baltijos šalyse gyvena tik 30000 vokiečių civilių. Jis pridūrè, kad Vokietijos kariuomenès dispozicija palei sieną yra tinkama priemoné norint sutrukdyti jiems ịžengti ị Prūsiją, bet netinkama - savanoriams sulaikyti. Nepaisant visų vokiečių pasiteisinimų, Komisija nusprende pakeisti sienų kontrolę ir prašè vokiečių imtis priemonių, kad būtų nutrauktas Rygos apšaudymas artilerijos sviediniais, sustabdytos atakos prieš Liepoją (Libau) ir nubausti įsakymams nepaklusę Vokietijos pareigūnai.

Kitą dieną Komisija ịvertino bendrą situaciją. Britų generolas Turneris paprašè nedelsiant siųsti Sąjungininkų kariuomenę ił Memelị (Klaipèdą), amerikiečių brigados generolas Čenis siūlè laukti, italų generolas Marietis teigè, kad trijų Sąjungininkų batalionų neužteks. Komisija pripažino, kad jis teisus, ir nusiuntė vieną telegramą Sąjungininkų Aukščiausiajai tarybai, prašydama daugiau kariuomenès, o kitą - vokiečiams, klausdama jų lèktuvų skaičiaus ir prašydama jų nenaudoti, ypač ryšiams su Vokietija palaikyti.

Po to Komisija persikèlè ị Tilžę ir susitiko su generolu V. Eberhardtu. Eberhardtas paaiškino savo veiksmus ir informavo komisiją, kad Rusijos ir Vokietijos pajeggas sudaro 49000 vokiečių, 10000 rusų ir 5 000-10 000 latvių, 150 lengvųjų patrankų, 50-60 sunkiụjų pabūklų, apie 40-50 vienetų karo aviacijos. Didesné šių karinių pajègų dalis buvo dislokuota prie Rygos. 1919 m. lapkričio 11 d. jis repatrijavo karinius padalinius, kuriuos sudaré apie 15000 vyrų, vèliau - dar 5 000-6 000 karių. Jis pridūré, kad yra 110 garvežiu ir apie 1000 vagonų. Eberhardtas manè, kad jo užduotis jau atlikta, tačiau Niselis liepe palaukti Sąjungininkų sprendimo.

Lapkričio $14 \mathrm{~d}$. Komisija pradèjo rengti susitikimus su Baltijos regiono valdžios institucijomis. Ji atkeliavo į Lietuvą per Eitkūnus. Čia turejo ilgai laukti lètai judančių Lietuvos garvežių, kurių kurui, visiškai nesant akmens anglies, buvo naudojama mediena. Komisija, ịvažiavusi $\mathfrak{i}$ Lietuvą, pastebejo, kad žmonès atrodo kitaip: kitokie buvo jų tiek fiziniai bruožai, tiek išvaizda.

Kauno $^{13}$ stotyje Komisiją sutiko Lietuvos ministras pirmininkas

13 Kaune (Kowno) buvo 30000 gyventojų, prancūzų misija, kuriai vadovavo pulkininkas Reboulas, ir britų misija, vadovaujama generolo Robinsono, kuris turejo reorganizuoti vietinę armiją. 
E. Galvanauskas ir karo ministras ir palydejjo ị Prezidento rūmus. Čia Komisijos narius prièmé prezidentas A. Smetona, kuris šiek tiek kalbejjo prancūziškai. Po pietų, apie 16 val., jie ir kalbejjosi.

Vèliau gen. Marietis rašè: Kowno yra labai panašus i rusiška miestą, jame namai - daugiausiai mediniai, tik vieno aukšto, retais atvejais - dvieju. Jame gyvena apie 30000 gyventoju, dèl to jis yra plačiai nusidriekęs. Šis regionas išsiskiria žemès ūkiu, neblogai pasidalinta nuosavybe. Daugelis žemès savininku paliko šia šali. Dèl penkerius metus trukusio karo ir Vokietijos eksploatavimo ši žemé siaubingai nukentëjo. Kowno mieste nèra né vieno namo su visais baldais. Kowno mieste yra britu misijos pulkininkas Robinsonas. Taip pat yra generolas, 2 pulkininkai ir dar keli anglu pareigūnai, kurie pertvarko kariuomenę. Ten taip pat yra pulkininko Reboulio vadovaujama Prancūzijos misija. ${ }^{14}$

Gen. Mariečio teigimu, kitą dieną Komisija susitiko su Lietuvos vyriausybe. Ten buvo daug Vokietijos agentų - sakẻ lietuviai, - iš kurių tikètasi gauti išteklių geležinkelio statybai, bet jie jų nedavè. Vokiečiai - piktinosi lietuviai - turejo net 50 diplomatinių asmenų Kaune, kai Berlyne buvo tik 10 Lietuvos atstovų, - taikiai misijai atlikti aiškiai per daug, - taip pat daug vokiečių žurnalistų, dirbančių spaudos agentūroje, o iš tikrųjų šnipinejjančių. Lietuviai minèjo, kad vokiečiai suskirstė teritoriją tarp geležinkelių Priekulè-Kretinga ir Šiauliai-Tauragè i 21 rajoną ir kiekvienam jų skyrè po vyriausiąji policijos pareigūną ir administracijos valdininką. Rinkimai buvo numatyti sausio ménesị.

Lietuvos valdžiai nebereikejjo vokiečių, kurie, anot vyriausybès, varè bolševikinę propagandą, žaidẻ biliardą ir smurtavo. Vokiečiai vis dar kontroliavo $440 \mathrm{~km}$ geležinkelio ir tyliai mažino vagonų skaičių. Lietuviai turejo geležinkelio darbininkų ir inžinierių, bet jiems trūko anglies, todèl buvo priversti naudoti medieną. Taip pat jie turejo 9 lèktuvus ir 10000 prastai atrodančių ir parengtų vyrų kariuomenę: 4 batalionai ir 2 baterijos buvo dislokuotos prieš bolševikus, 2000 vyrų - Lenkijos pasienyje, visi kiti - netoli Chadowo (Šeduvos?), kad saugotų geležinkelị ir būtų rezervas kovoje su „raudonaisiais“. Vyrai prie Chadowo turejjo pusès bataliono rezervą, kita pusè laikẻ liniją, dar vienas batalionas buvo Kaune.

14 AUSSME, Fondo E 8 - Registro Commissione Interalleata di Parigi, Raccoglitore n. 99 - Stati Baltici, Commissione interalleata - diario della delegazione italiana - novembre 1919 - novembre 1920, page 19. 
Kiekviename batalione yra po 800 vyru, 3 baterijas, kurias sudaro 4 pabūklai ir rusiški kariniai ištekliai, ir vieną baterija Kaune. Turi viena visiškai suformuota ir viena nebaigta formuoti eskadronus. Tauragés mieste [yra] 50 vyrų, kuriuos nuginklavo vokiečiai (jie prašys grąžinti ginklus). 9 lèktuvai, viena iš ju paèmè vokiečiai, kiti 8 - naujo tipo, metaliniai, naudojami prieš bolševikus, nusileidžia Lietuvos teritorijoje. Apie 2000 savanoriu tarnauja vietos gynyboje. Ginklus jiems pardave vokiečiu kariai.

Karo planas. Ju tikslas bütu daug apimantis: norètu pulti vokiečius, bet jiems trüksta amunicijos; jie bandè gauti amunicijos iš Lenkijos, bet nesutarę dèl sienu šio reikalo neužbaige. ${ }^{15}$

Trumpai tariant, Lietuvos vyriausybè praneše Komisijai norinti pulti vokiečius, tačiau neturinti amunicijos. Ji paklausẻ lenkų, ar nesuteiktų pagalbos, bet jie atsisakè.

Komisija patare kol kas nesiimti iniciatyvos, likti budeti, kad tinkamu metu galètų pulti vokiečius ar jų sandèlius Šiauliuose. Komisija prašè Paryžiaus paspausti Lenkiją, kad pastaroji nebūtų priešiškai nusistačiusi Lietuvos atžvilgiu, kurios pilietinè organizacija atrodè patikima, tačiau karinè dar nebuvo pakankamai gera.

Tarptautinè situacija pasirodè esanti dar sudètingesnè. V. Eberhardtas sutiko trauktis ị Rytų Prūsiją, bet, kad ịvyktų realus Vokietijos pasitraukimas, Komisijai reikèjo, kad Latvija ir Lietuva neveiktų prieš vokiečius. Kitaip vokiečiai tikrai atšauktų karius iš Rytų Prūsijos, o Lietuva - tikrai - ir Latvija - galbūt - būtų sunaikintos. Tada atsirado problemų dèl Rusijos „baltujjų“ pajègų, daugiau ar mažiau vadovaujamų Bermonto, Vokietijos Geležinès divizijos, Plehwe grupès, Baltijos landvero, kurị sudare 2600 gerai ginkluotų vyrų, pasak Komisijos, veikiančiu suderinus veiksmus su latviais ${ }^{16}$.

Vèliau ịvyko kitas susitikimas su vokiečiais. Jis buvo lengvesnis dèl naujienos, kad P. Bermontas sutiko veikti pagal Komisijos nurodymus. Vokiečiai bijojo Latvijos atakos - $17 \mathrm{~d}$. ji vis tiek prasidejo - tai buvo

\footnotetext{
15 AUSSME, Commissione interalleata - diario della delegazione italiana - cit., page 20.

16 Generolo Turnerio gautomis žiniomis, Baltijos landvero (Landwehr) grupę sudare asmenys, kuriuos politiškai galima būtų padalyti ị tris kategorijas: provokiškos, prolatviškos orientacijos ir nežinančius, kurią pusę pasirinkti. Manoma, kad paskutinị lapkričio dešimtadienị trečioji kategorija tapo prolatviška, bet niekas tiksliai nežinojo, kokia bus visos landvero grupès elgsena.
} 
pagrindinè priežastis neatsisakyti bendradarbiauti. Pasiekus susitarimą, admirolas Hopmanas sutiko perkelti Vokietijos kariuomenę, veiksmus kontroliuojant mišriai Sąjungininkų, latvių ir lietuvių komisijai. Sąjungininkų pareigūnai privalèjo tikrinti išvykstančius vokiečius, latviai ir lietuviai perimti jų paliekamų teritorijų kontrolę. Vokietijos kariuomenè turèjo pasitraukti dviem geležinkelių linijomis - Mintauja-Tilžè ir PriekulèKlaipèda (Priekulie-Memel). Atsitraukianti kariuomenè galejo naudotis ir šalia geležinkelių einančiais keliais, maršrutas tarp Šiaulių ir Tauragès pagal spalio $30 \mathrm{~d}$. Vokietijos ir Lietuvos paliaubų reikalavimus turèjo būti saugus. Kariuomenių judejjimo metu vokiečiai ir Sąungininkai privalèjo visiškai kontroliuoti dvi stotis: Murawievo ir Tukumo, o Sąjungininkų pajègų pareigūnai - keliauti kartu su Latvijos ir Lietuvos vyriausybių atstovais, kad perimtų išvykstančių Vokietijos administracijos pareigūnų pozicijas. Lietuvių ir latvių prašyta ramybès: nekirsti spalio $30 \mathrm{~d}$. sudarytų paliaubų linijos be Komisijos žinios ir nesuteikti vokiečiams akivaizdaus preteksto pareikšti protestą ir sustabdyti kariuomenès išvedimą.

Nuspręsta, kad rusus reikia išsiųsti Judeničiui, o jis nuspręs, kurie iš jų galètų būti ịtraukti ị jo karių gretas. Visi kiti daliniai turejo trauktis ị Rytų Prūsiją, iš ten - $\mathfrak{i}$ Vokietiją, kur būtų išformuoti, jei nesudarytų reguliariosios kariuomenès dalies.

Lapkričio $20 \mathrm{~d}$. vokiečiai pareiškè protestą, kad lietuviai juos puldinèja, ypač ties Šiauliais ir Radviliškiu, taip pat kad vyksta veiksmai aplink Telšius ir Raseinius. Tai reiškè, kad vokiečiai negalèjo naudoti geležinkelio, be to, latviai vis dar nebuvo atsakę i Vokietijos pasiūlymą dèl paliaubų. Vokiečiai taip pat prašè leidimo prie Lyduvènų tilto dislokuoti apsaugos kariuomenę, kad ji užtikrintų atsitraukimo saugumą. Komisija sutiko, bet leido dislokuoti ne daugiau kaip 400 vyrų, be artilerijos ir sunkiųjų pabūklų. Viskas turejjo vykti kontroliuojant mišrioms Sąjungininkų ir Lietuvos pajejgoms, o Vokietija - lydèti traukinius, išvežančius evakuojamą kariuomenę. Galiausiai per aštuonias dienas palei liniją nuo Priekulès iki Klaipėdos neturejjo likti vokiečių. Komisija didino spaudimą Lietuvos vyriausybei ragindama stabdyti atakas, kitaip bus neįmanoma atitraukti Vokietijos pajègų. Telegramoje Lietuvos vyriausybei rašoma: Jūs patys turite büti suinteresuoti, kad Vokietijos pasitraukimas vyktu sklandžiai. Atrodo, ketinate siusti bataliona $i$ Taurage, tačiau tai neįmanoma. Jei veiksite ne pagal mūsu plana, negalèsime igyvendinti savo misijos. Jei vokiečiai 
iškrès pokštą, nedelsiant jums pranešime. ${ }^{17}$

Komisija nerimavo, nes gavo informacijos iš Kaune esančio Prancūzijos pulkininko G. Reboulio, kad vokiečiai įžūliai plěšikauja šioje teritorijoje. Jis prašè perduoti Lietuvai Šiaulių kontrolę ir sutelkti išeinančią kariuomenę palei Priekulès-Klaipèdos liniją. Komisija atmetè ši pasiūlymą, nes jai buvo svarbiau kiek imanoma pagreitinti Vokietijos kariuomenès perkèlimą, kad plèšimo mastas dar labiau nepadidètų.

21 d., keliaujant ị Tauragę, traukinyje ịvyko susitikimas su vokiečiais. Hopmanas pranešè Komisijai, kad latviai atmetė Vokietijos paliaubų pasiūlymą. Latvijos kariai vis dar kovojo su vokiečiais, susirèmimai vyko aplink Priekulę, Vokietijos kairèje, ir Bauskejje, jos dešinèje, tačiau abi pusès teigè turinčios savo rankose Bauskę, Mintaują, Katharinhofa ir Sckwetau (pastarąj užèmè Latvijos kavalerija). Tauragèje Komisija klebono namuose susitiko su vietos Lietuvos bataliono vadu.

Tiesą sakant, Komisija veikè turèdama tam tikrų abejonių, bet ne blogų ketinimų. Ji neleido Tauragèje niekam kurti savo stovyklų, ìsakẻ lietuviams priimti Vokietijos atstovą savo batalione ir patare tiek vokiečiams, tiek lietuviams kiekvieną incidentą fiksuoti. Lietuvos batalionas galèjo užimti tik Tauragę ir negalèjo būti per arti geležinkelio. Vokiečiams buvo įsakyta nedelsiant išlaisvinti visus Lietuvos kalinius, kuriuos suèmé dèl politinių priežasčių, lietuviai buvo paprašyti to paties. Ginklus, priklausančius vokiečiams kaliniams, turèjo lietuviai, kol vokiečiai grąžins ginklus, kuriuos konfiskavo iš 50 Lietuvos karių, nuginkluotų Tauragèje prieš kelias dienas. Tuo metu Komisijai buvo pranešta iš Helsinkio, kad N. Judeničius veda derybas su Estijos vyriausybe dèl savo kariuomenès atitraukimo ị Estiją, kad galètų palikti pozicijas M. Rodzianko ar Gurko, kurie buvo provokiškos pakraipos, - tada naujas Estijos ir Rusijos pajègu vadas būtų Leiteneris, P. Bermontas ketino savo postą palikti Jawitui.

Komisija išsiuntė dvi telegramas: vieną - i Rygą, prašydama Latvijos vyriausybès nekliudyti Vokietijos kariuomenei išeiti, kitą - ił Kauną, kurioje to paties buvo prašoma Lietuvos vyriausybės, kurios kariai buvo atkirtę geležinkelio liniją Šiauliai-Jelgava. Visi Komisijos nariai, išskyrus Niselị, mané, kad dabar pats metas stabdyti latvius, kitaip jų veiksmai pavers tvarkingus vokiečių dalinius ị nekontroliuojamų vyrų su ginklais

17 AUSSME, Commissione interalleata - diario della delegazione italiana - cit., page 29. 
minią ir jų evakuacija taps neįmanoma. Kitą dieną generolas Marietis ittikino Niselị būtinai stabdyti latvius. Pagaliau Niselis sutiko ir pasiuntė Ł Rygą telegramą: Vokiečiai išvyksta. Sustabdykite išpuolius. Netrukdykite evakuacijai. Nekirskite Latvijos-Lietuvos sienos, nustatytos Paryžiuje ${ }^{18}$.

23 d. pasiekè blogos naujienos. Vokiečiai paliko Mintaują ir atsitraukè ¡ Ł Šiaulius, latviai išstūmė vokiečius iš Bauskès ir ketina pulti Šiaulių kryptimi, tačiau nesirengia peržengti sienos. $22 \mathrm{~d}$. lietuviai puolè geležinkelị tiek ị šiaurę, tiek ị pietus nuo Šiaulių, nepaisydami susitarimo, pasiekto spalio 31 d., laikyti geležinkelị neutralia zona, kad vokiečiai galètų saugiai atsitraukti. Be to, lietuviai atakavo ir Šiaulius, todèl Vokietijos karo ministerija pasiuntė karius ginti Šiaulių ir saugoti geležinkelio. 23 d. Komisijai vienas jos agentas, pulkininkas Dosė (Dosse), pranešè, kad Lyduokiuose geležinkelio darbas buvo nutrauktas 24 valandoms. Atėję derètis Lietuvos pareigūnai išgirdo atsakymą, kad jie turi nustoti kautis ir trauktis, tačiau ir vèliau pasitraukimas nevyko. Lietuvos vyriausybe pasisiūlè imtis išimtinès evakuacijos proceso kontrolès. Komisija atsakè, kad Sąjungininkų ir Lietuvos pajègų vykdoma kontrolè yra pakankamai gera, ir, jei lietuviai primygtinai reikalaus, Sąjungininkai pakeis savo draugišką požiūrị i juos. Komisija paragino Lietuvos batalioną palikti Tauragę ir išsiuntė telegramą i Berlyną, ragindama Vokietijos karo ministrą nesiųsti reguliariosios kariuomenès saugoti atsitraukiančių karių.

Pamažu situacija pradejo keistis. Lietuviai buvo priversti priimti paliaubų sąlygas. Vokiečiai neišvedè savo kariuomenès iš Rytų Prūsijos. Lietuviai paliko Tauragę, kovos liovèsi beveik visur, net latviams užpuolus Plehwe grupę.

$24 \mathrm{~d}$. britų generolas $\mathrm{H}$. Turneris nusiuntė Liepojos vyriausybei telegramą, prašydamas stabdyti latvius. Jų spaudimas buvo stiprus, tik link Šiaulių judanti Geležinè divizija, kuri ketino užimti miestą, priešinosi. Siekdama užkirsti kelią didesniam susidūrimui, Komisija nusprendè pasiūlyti lietuviams užimti Šiaulius. Jei lietuviai sutiktų, būtų latvių ir vokiečių kovos pabaiga. Tai buvo perduota Lietuvos generolui S. Žukauskui ${ }^{19}$, išsiųsta ị Rygą telegrama, kad Lietuvos kariuomenè užimtų pozicijas ị šiaurę ir

\footnotetext{
18 AUSSME, Commissione interalleata - diario della delegazione italiana - cit., page 31.

19 Marietis rašè, kad Komisija laikė Žukauską (Mariečio užrašuose parašyta Jukowski) vieninteliu tikru Lietuvos generolu, bet Lietuvos kariuomenės vyriausioji vadovybè įtarè ji esant prolenkiškos pakraipos, todèl vadovauti buvo patikèta generolui Liatukui. Ten pat, cfr. op. cit., page 37.
} 
vakarus nuo Šiaulių, palaikytų tvarką ir saugotų Vokietijos pasitraukimą.

Ryga atsakè 24 valandoms stabdanti visas operacijas, tačiau perspejo, kad latviai pasirengę jas pradèti iš naujo, jei vokiečiai neišvyks.

Tai buvo lūžis. Lapkričio 24 d. 10000 Geležinès divizijos vyrų atsitraukè ir bandè pasiekti tarp Šiaulių ir Murawievo esantị geležinkelį, 5000 rusų ir vokiečių kareivių atsitrauke iš Tukumo ì pietus, 4000 vyrų, sudarančių Vokietijos legioną, - i Šiaulius, visa evakuacija turejjo baigtis iki gruodžio $13 \mathrm{~d}$.

Tą pati vakarą Vokietijos vyriausybė paprašė Lietuvos neatkirsti geležinkelio, kad jos kariai galètų išvykti iš Baltijos provincijų. Lietuvos vadovybè sutiko.

Žinoma, vis dar buvo problemų. Buvo deklaruojama, kad Vokietijos traukiniai veža karo pabėgèlius, o iš tikrųjų dažnai, jei ne visada, veždavo karinius išteklius, kuriuos vokiečiai turejjo palikti lietuviams arba latviams. V. Eberhardtas ragino stabdyti arba bent sulètinti atsitraukimą. Vokiečiai telkèsi aplink Šiaulius ir Šiauliuose, teritorijoje buvo išsisklaidę 2500 vyrų, 9 iš jų buvo nušauti. Komisija nusprendè, kad pirmieji 5 ar 6 traukiniai su pabègèliais turi pajudèti, tada bus imtasi ginkluotų vyrų iš iširusių karinių dalinių evakuacijos.

Vokiečiai traukèsi lètai. Komisija pastebejo, kad Lietuvos Dūmos netenkina (turèta omenyje Lietuvos Valstybès Taryba - mokslinis redaktorius), kaip pati Komisija veikia. Buvo manoma, kad Komisijos veikla net yra priešinga Lietuvos interesams ${ }^{20}$.

Vakare Komisija gavo pranešimą, siųstą Vokietijos vyriausybès Lietuvos vyriausybei. Jame lietuviams sakoma, kad Vokietija nusprendè išvesti savo karius iš Baltijos šalių, bet tai padaryti bus neįmanoma, jei bus atkirstas geležinkelis. Traukinys su sužeistaisiais ir pabėgèliais - teigè vokiečiai - laukè išvykimo, bet buvo apšaudytas artilerijos sviediniais, todèl Vokietijos vyriausybè prašo netrukdyti vokiečiams išvykti ir siūlo atiduoti lietuviams nemokamai visas geležinkelio statybines medžiagas ir karinės paskirties išteklius, kuriuos ketino čia palikti, kai baigs gabenti karius. Atsakymo laukiama iki kitos dienos, lapkričio 28-osios, vidurdienio. Gavus neigiamą atsakymą arba negavus jokio, būtų pasiųsta papil-

20 Anot Mariečio, gruodžio 2 d. Komisijai buvo pranešta, kad Lietuvos vyriausybė sumanė paduoti ị karo teismą pulkininką K. Ladigą, kaltinamą aklai vykdžius Sąjungininkų vadovybės įsakymus. Komisija nusprendè paspausti vyriausybę ir išspręsti šị klausimą. 
doma kariuomenè.

Komisija sureagavo. Atsakyti reikejjo labai greitai. Ji suprato, kad šis pranešimas, kuriame nurodytas toks trumpas terminas, yra tik pretekstas teigti, kad, tai padaryti pavèlavus, Vokietijos gerą valią išniekino patys lietuviai, nesiteikę atsakyti, tad dèl šios priežasties vokiečiai buvo priversti pasiųsti dar karių i Lietuvą. Lapkričio 27-osios naktị Komisija išsiuntė Vokietijai ir Lietuvai pranešimą, kuriame teigiama, kad Lietuva, jų žodžiais, nutraukė visas atakas, o jei būtų toliau atakuojama, Komisija prašytų Vokietijos pasiųsti papildomą kariuomenę. Kaunas, nepaisant generolo P. Liatuko prieštaravimo, pateikẻ skundą dèl Komisijos kišimosi i lietuvių operacijų planus.

Kitas pranešimas buvo išsiųstas, kad Komisija palaikytų ryši su Latvijos ir Lietuvos pajėgomis, puolančiomis vokiečius Baltijos šalyse. Kaip riziką ribojančios priemonès Komisija paprašė Sąjungininkų pajėgų Aukščiausiosios tarybos daryti spaudimą Vokietijai, jei bent dalis Vokietijos kariuomenès būtų persiųsta iš Rytų Prūsijos ị Lietuvą besitraukiančių vokiečių paremti.

28 d. kilo riaušès dèl Klaipèdos. Jas sukèlè Plehwe grupès kariai. Dèl Vokietijos vyriausybès požiūrio Latvija nutraukè diplomatinius santykius su Vokietija ir suemė Vokietijos konsulą Hluką (Hluck) ir dar 25 asmenis Skuddi (?) mieste. Tą pačią dieną Latvijos kariams buvo ịsakyta pasiekti Lietuvos sieną ir pervesti per ją savo lengvąją kariuomenę. Tai buvo galutinis postūmis. Tą naktị vokiečiai pradejjo realią evakuaciją. Penki traukiniai pajudejo ị Rytų Prūsiją iš Memelio (Klaipèdos) ir Schawli (Šiaulių), o generolas S. Žukauskas paprašè Komisijos leidimo išsiųsti Lietuvos batalioną i Murawievo tikrinti evakuacijos proceso ir saugoti geležinkelio. Komisija neleido. Atsake, kad pakanka ir vietinių Lietuvos kontrolès pareigūnų. Bet 29 d., pasklidus gandams apie Latvijos ketinimą užimti Murawievo, Žukauskas nusiuntè ten savo atstovus ${ }^{21}$.

Gruodžio $1 \mathrm{~d}$. Žukauskas pareikalavo, kad vokiečiai atiduotų lietuviams 10000 arklių ir daug kitų išteklių. Jis kaltino juos veiksmų lètumu, savo žodžio nesilaikymu ir pažadètų lietuviams karinių išteklių išgabenimu. V. Eberhardtas atsakè, kad viskas vyksta lètai, nes jis gali naudotis

${ }^{21}$ Latviai protestavo, kad lietuviai gavo daug karinių išteklių, o jie negavo nieko, todèl, matydami, kad vokiečiai palieka sandèlius ir artilerijos reikmenis Murawievo mieste, ketino ji užimti. 
tik viena geležinkelio linija. Jis nebuvo tikras, ar evakuacija galètų baigtis gruodžio 13 d., be to, pareiškè, kad yra puolamas latvių, o lietuvių kariai tuo metu telkiami Radviliškyje. Komisija piktai atsakè, kad dèl ilgo vokiečių buvimo visiškai pateisina Latvijos išpuolius, o Lietuvos pajègų telkimas prasidèjo dèl nekorektiškų Vokietijos pažadų išteklių perdavimo klausimu. Bet kokiu atveju, jei pats V. Eberhardtas liktų Šiauliuose tol, kol pasitrauks paskutiniai kariai, ir laikytųsi savo žodžio dèl paliekamų išteklių, Komisija užtikrintų Eberhardto ir jo vyrų saugumą lydinčiu Sąjungininkų ir Lietuvos pareigūnų jẻgomis.

Vokietijos evakuacija vyko be didelių nesklandumų. Jų atsirado po kelių dienų, kai atėjo laikas išvykti Geležinei divizijai. Gruodžio $3 \mathrm{~d}$. ji dar nebuvo gavusi tiesioginio įsakymo. Latviai nervinosi, norejo, kad divizija kuo greičiau išvyktų, tačiau ji delsẻ. Savo ruožtu lietuviai taip pat protestavo. Vokiečiai įžǔliai plèšikavo daugelyje skirtingų vietų, todèl Kaunas norejo priartinti savo karines pajègas, kad jos būtų $3 \mathrm{~km}$ atstumu nuo geležinkelio.

Tą pačią dieną Komisija iškèlè hipotezę dèl bendros Latvijos ir Lietuvos operacijos prieš vokiečius. Estai negalejjo ịsikišti dèl atstumo ir dèl to, kad jų kariuomenè, N. Judeničiaus kariuomenei žlugus, turëjo išlaikyti liniją prieš sovietus palei Narvos upę.

Pagal planus vokiečiai turèjo likti saugioje teritorijoje, 5-6 km nuo geležinkelio, tačiau jiems neatsitraukus latviai galëjo pulti didžiąją Geležinès divizijos dali tarp Kuršènų ir Šiaulių. Netrukus po to Lietuvos kariai turejo pulti Radviliškị ir Šiaulius ir taip atkirsti geležinkelị kuo labiau ị pietus, kad užkirstų kelią bet kokiam Vokietijos pajègų pastiprinimui iš Rytų Prūsijos atvykti. Kairijji sparną ir Geležinès divizijos užnugarị būtu puolę latviai iš Liepojos. Taip būtų sutrukdyta Vokietijos kariams pasitraukti $\mathfrak{i}$ Klaipèdą ir Šilutę ir neliktų galimybès jiems sulaukti pastiprinimo.

Sąungininkų Aukščiausioji taryba apie tai buvo informuota, tačiau atsakyta, kad Komisijos misija nenumato tokių veiksmų. Akivaizdu, kad gandai plito, todèl nenuostabu arba bent jau ne taip nuostabu, kad tą pačią dieną Geležine divizija pažadejjo išsykti kitą rytą.

Bet, sužinojus šią naujieną, buvo gautas pranešimas, kad vokiečiai naikina ir plěšia Šiaulius. Generolas S. Žukauskas su keliais savo daliniais pasitrauke, tačiau iki gruodžio $6 \mathrm{~d}$. generolas P. Liatukas paprašè leidimo priartèti prie geležinkelio $3 \mathrm{~km}$ atstumu. Komisija išsiuntè Lietuvos 
vyriausybei ilgą telegramą. Ji teigè, kad vokiečiai ketina išvykti kitą rytą. Komisija suprato, kokia susierzinusi gali būti Lietuvos vyriausybè dèl nelojalaus Vokietijos elgesio: faktiškai vokiečiai nepaliko išteklių, kuriuos ketino nemokamai perleisti lietuviams, bet Komisija pažadejjo priversti Vokietijos vyriausybę atiduoti Lietuvai viską arba bent jau tiek, kiek buvo pažadèta, pataisyti, kas buvo sugadinta, atpirkti, kas buvo išplěšta ir pavogta. Komisija paprašé Lietuvos vyriausybès nesikišti, kad nebūtų daugiau rūpesčių.

Iš tiesų Geležinès divizijos vyrai stengèsi padaryti kuo daugiau žalos. Namai, bažnyčios ir parduotuvès buvo apiplèštos ir sudegintos, žmonès žudomi, tačiau evakuacija prasidejjo ir vyko. Vakare generolas P. Liatukas išsiuntė Komisijai dar vieną telegramą: protestuodamas prieš vokiečių kareivių vykdomus grobstymus ir naikinimą, jis vèl praše leidimo gruodžio $6 \mathrm{~d}$. priartinti Lietuvos kariuomenę $3 \mathrm{~km}$ iki geležinkelio.

Komisija nusiuntė Kaunui kitą telegramą. Joje atsakè, kad prieštarauja visiems veiksmams, kurių anksčiau nebuvo patvirtinusi. Gruodžio 4 d., po pietų, pirmasis traukinys išgabeno 3-iojo pèstininkų pulko personalą ir batalioną. Balandžio $5 \mathrm{~d}$. išvyko Peterkovo Freikorpo grupè. Armijos atsitraukimas nebuvo lengvas. Gruodžio 4 d. 9 valandą ryto p. Zalkuskas Komisijai pranešè, kad vokiečiai grobia prekes ir galvijus, naikina privačią nuosavybę, pleš̌ia viešąsias ịstaigas ir bažnyčias, nužudyta žmonių. Jis prašè grąžinti tai, kas pavogta, ir priversti vokiečius atlyginti visą žalą.

Vèl atsinaujino statybos medžiagų ir karinių išteklių perleidimo problema. Lietuvos vyriausybẻ parengè ilgą sąrašą. Diskusijos vyko gruodžio 4-5 d. ir vèliau. Vokiečiai piktinosi, kad reikalaujama grąžinti per daug. Lietuviai ir Komisija atsakè, kad žalos atlyginimą jie galètų priimti ir pinigais. Vokiečiai atsake „taip“ - bet tik dèl žalos atlyginimo, kurią padaré vokiečių kariai, o ne kiti daliniai. Nesvarbu, Komisija atsakè: mes sakème iš pat pradžių, kad laikome jus visus vokiečiais, nes visi veikète pagal Vokietijos atsakomybę, reikalavome, kad vokiečiai atiduotų lietuviams visus išteklius İsrutyje (Insterburg) ir Tilžèje. Po ilgų diskusijų admirolas Hopmanas pažadejo duoti Latvijai ir Lietuvai geriausios kokybès medžiagụ geležinkelio statybai. Tą pačią dieną Komisija sužinojo, kad Geležinè divizija pajudejjo, kirto Šiaulius ir tikriausiai nužygiavo ị Tilžę. Tai buvo ne visai tai, ką turëjo padaryti, bet vis dèlto ji išvyko iš Latvijos. Ir tai buvo rezultatas.

Lietuvos valdžia buvo perspeta, kad būtu pasiruošusi užimti geležinkelị, Latvijos paprašyta būti pasirengusiai paremti lietuvius. 
Birželio 6 d. V. Eberhardtas pranešè, kad, įvertinęs susiklosčiusią padètị ir ankstesnes daugkartines latvių ir lietuvių atakas, jis negalètų naudotis geležinkeliu ir pageidautų žygiuoti i̇ pietus. Tiesą sakant, atrodè, kad nebuvo jokių atakų: tiek latviai, tiek lietuviai, pasak Komisijos, buvo pasirengę intervenciniams veiksmams ir laukè tolesnių Komisijos nurodymų. Matydama, kokia paini situacija, Komisija leido lietuviams užimti dali geležinkelio, bet įsakè praleisti visus išvykstančius traukinius, kitais žodžiais: jie turejo užtikrinti apsaugą ir sklandų traukinių judejimą, tad tą pačią dieną Lietuvos kariai užèmė Šiaulius. Vokiečiai protestavo ir paprašè atidèti Šiaulių okupaciją iki gruodžio 8 d., Pogrysowos ir Lyduvènų - iki gruodžio 10 d., o visą geležinkelị užimti ne anksčiau kaip gruodžio 12 d., tačiau Komisija patvirtino savo įsaką ir - po Mariečio pasiūlymo - pareiškè, kad netvarkos atveju generolas V. Eberhardtas bus laikomas vieninteliu atsakingu asmeniu.

Gruodžio $7 \mathrm{~d}$. Lietuvos vyriausybei buvo išsiųsta telegrama, kurioje raginama organizuoti griežtą Lietuvos sienos tarp Tauragès ir Klaipèdos kontrolę, kai tik baigsis vokiečių evakuacija, siekiant išvengti galimų susiremimų. Tuomet Rygos ir Kauno vyriausybès buvo pakviestos susitarti dèl Lietuvos teritorijos gynybos.

Gruodžio $8 \mathrm{~d}$. pasiekè naujiena, kad paskutiniai Geležinės divizijos daliniai išvyko, bet prieš išvykdamas vokiečių legionas susprogdino artilerijos reikmenų sandèlius, padegè kelias maisto ir drabužių parduotuves.

Gruodžio $9 \mathrm{~d}$. pirmiausiai Komisija išsiuntė Paryžiui ilgą pranešimą, kuriame buvo pateikta daugybè klausimų. Komisija turejjo priversti vokiečius atiduoti lietuviams geležinkelị ir karinès paskirties išteklius, kuriuos žadejo, ir dar pridèti gerą pinigų sumą, kad atpirktų žalą, padarytą atsitraukiančių karių tiek Latvijai, tiek Lietuvai. Šiek tiek vèliau tą pačią dieną Hopmanas pranešè Komisijai, kad apie 16000 vyrų evakuota ị Rytų Prūsiją. Geležinè divizija vis dar turèjo sutelkusi 6000 karių 20 km atstumu nuo valstybès sienos, kurią jie turèjo kirsti iki gruodžio $13 \mathrm{~d}$. Sieną saugojo nustatytu atstumu stovintis pulkas, atsakingas už saugumą ruože tarp Kretingos ir Šilutès. 5000 Vokietijos legiono vyrų buvo likę prie Batakių, apie $20 \mathrm{~km}$ nuo Tauragès. Jie žygiavo link Tilžès ir, tikètina, gruodžio $12 \mathrm{~d}$. turèjo kirsti sieną.

Tai buvo gera žinia. Hopmanas gavo kelis sąrašus: viename buvo išvardytos geležinkelio statybai skirtos medžiagos, kitame - karo paskirties 
reikmenys, kuriuos vokiečiai turejo atiduoti Latvijai ir Lietuvai. Be to, kontrolès komisija, kuriai pirmininkavo generolas Vincentas, būtų pasiuntusi Sąungininkų pajègas ị Virbalị ir Poscheruni kontroliuoti minimų vokiečių išteklių perdavimo lietuviams. Galiausiai po kelionès po Baltijos šalis Komisija būtų nurodžiusi vokiečiams tikslų arklių ir galvijų skaičių, kartu ir ịvardijusi pinigų sumą, perduotiną Latvijai ir Lietuvai.

Komisija nusprendè vykti ị Rygą su Latvijos vyriausybe aptarti visų „kabančių“ klausimų, pavyzdžiui, išteklių, žalos atlyginimo ir pan. Ji issteige 5 pakomises. Viena turejjo vykti ỉ Berlyną ir priversti vokiečius perleisti Baltijos šalims geležinkelius ir karinès paskirties medžiagas, kitos keturios - viską patikrinti ir pranešti apie vokiečių padarytus nuostolius, destrukciją, nusikaltimus ir plèšimus. Pakomisès vyko į Liepojos, Šiaulių, Mintaujos ir Telšių apylinkes; pastarojoje išvykoje dalyvavo ir Italijos pareigūnas su dviem savo šalies kariais.

$11 \mathrm{~d}$. V. Eberhardtas bandè konstatuoti, kad evakuacija vèluoja, tačiau Komisija atsakè, kad jo visi kariai turi būti Rytų Prūsijoje gruodžio $13 \mathrm{~d}$. Vis dar vyko diskusijos su Hopmanu dèl išteklių, kuriuos reikejjo atiduoti lietuviams ir latviams, kai gruodžio $13 \mathrm{~d}$. pasieke informacija, kad visi Vokietijos reguliariosios ir nereguliariosios kariuomenių daliniai, išskyrus silpnus ir mažus ariergardo, kirto sieną ir Vokietijos geležinkelio personalas išvyko iš Šiaulių 15 val., o lietuviai visiškai kontroliuoja geležinkelị iki sienos.

Diskusijos vyko toliau. Buvo nuspręsta steigti technines komisijas vokiečių išteklių perdavimui Baltijos šalims kontroliuoti. Vokiečiai bande parduoti išteklius, bet Komisija priminè, kas buvo nuspręsta karo ministro vardu lapkričio 24 d., ir atmetė bet kokio mokèjimo už paliktus išteklius galimybę. Lietuvos atstovas Komisijai perdavè, kad jo vyriausybė ką tik pranešè Vokietijai, esą lietuviai pageidauja turèti Komisiją kaip savo tarpininką dèl pretenzijų Vokietijai, tačiau Vokietijos vyriausybè atsisakè, todèl Niselis informavo Hopmaną pagal instrukciją, duotą Paryžiuje, kad Komisija turi reguliuoti ir prižiūrèti viską, kas susiję su evakuacijos, ùkio atkūrimo ir atstatymo reikalais. Tuo pat metu išsiųsta telegrama ị Paryžių, kuria buvo pranešama Sąungininkų Tarybai, kad Vokietija bandè pati užmegzti pokalbị su Lietuva. Hopmanas teigè, kad, kalbant apie atstatymą ir išteklius, Vokietijos vyriausybė nori, kad lietuviai atvyktų i Berlyną, nes šią situaciją reikia aptarti tiesiogiai. 
Gruodžio 17 d. Komisija atvyko į Rygą. Ją prièmé premjeras K. Ulmanis ir užsienio reikalų ministras Z. Mejerovicas. Kitą dieną ịvyko Latvijos vyriausybės ir Komisijos susitikimas. Latviai pristatė vidaus situaciją, buvo išnagrinètos aktualios problemos, susijusios su Vokietija. Sausio 19 d. Komisija Rygoje susitiko su Estijos delegatais. 21 d. ịvyko antrasis susitikimas su Latvijos vyriausybe. Latviai pateikè sąrašą, pagal kurị karo nuostoliai siekè $283 \mathrm{mln}$. Jie pridūrè, kad armija numate $5 \mathrm{mln}$. išlaidų dienai, kad vokiečiai pasisavino 6000 arklių.

Po kelių dienų Komisija persikèlė ị Lietuvą. Gruodžio 24 d. ji nagrinejjo karo nuostolius, padarytus Rosbacho būriui priklausančių vokiečių Mintaujos mieste: buvo sudeginta senovinè pilis, muziejus ir gimnazija, sudege 20000 ir 50000 bibliotekos knygų ir ten saugoti reti rankraščiai. Tą pačią dieną po pietų Komisija atvyko ị Šiaulius ir atliko panašų patikrinimą, o nakti pasiekè Kauną.

Per Kalėdas Komisija susitiko su Lietuvos vyriausybe. Ministras pirmininkas dar kartą paprašè vokiečių grąžinti pavogtus arklius ir galvijus. Lietuva - agrarinè šalis - sakè jis, - ir ji labai nukentejjo nuo karo padarinių, todèl vyriausybės pirmoji užduotis - kuo greičiau atkurti žemès ūkį.

26 d. Komisija paliko Kauną. Sąjungininkų Aukščiausioji taryba savo telegramoje pranešè, kad jos darbas baigtas. 1919 m. gruodžio 28 d. ji nuvyko ị Berlyną ir liko ten rūpintis visomis detalèmis, susijusiomis su žalos, kurią padarè vokiečiai Baltijos šalyse, atlyginimu. Komisija liko Berlyne iki 1920 m. sausio 16 d. Paskui išvyko į Paryžių. Čia pristatè savo ataskaitą Ambasadorių konferencijoje, o 1920 m. vasario 3 d. oficialiai buvo išformuota. Priimta paskutinè Komisijos rekomendacija: nepalikti Baltijos šalių ir jas remti. Po mažiau nei 20 metų paaiškèjo, kad niekas jos nepaisè.

Iteikta $2012 \mathrm{~m}$. spalio $9 \mathrm{~d}$. 


\title{
ÉVACUATION DES ALLEMANDS DE LITUANIE EN 1919 À VUE D'OEIL DU MEMBRE DE LA COMMISSION INTRA ALLIÉE DE L'ITALIE : ANNÉES 1919 OCTOBRE-DÉCEMBRE
}

\author{
Dr. Ciro PAOLETTI
}

En automne des années 1919 les allemands étaient toujours en Lituanie et, en partie, en Lettonie, les gentilshommes baltiques avaient envie de sauver ses fortunes, et ils supportaient les allemands qui attendaient toujours de l'annexion. Néanmoins, après la défaite, l'Allemagne ne pouvait pas exprimer ses buts de l'annexion, pour cette raison elle a exploité ses unités de P.Bermont-Avalov, disloquées en Lettonie et Lituanie.

Les coalisés observaient toute la situation à Paris, mais ils nétaient pas aussi divisés. Les États-Unis et l'Italie n'avaient pas des intérêts politiques dans la région des pays baltes, pendant que la France avec la Grande Bretagne étaient intéressées. Les britanniques ambitionnaient d'entrer en guerre contre les communistes l'indépendance totale de chaque pays baltique. Sur ces entrefaites, les français souhaitaient des résultats qui soient favorables pour la politique étrangère pratiquée. Dès la deuxième partie du XVIème siècle, ils prétendaient de former beaucoup de tracasseries pour l'Allemagne et pour la dynastie des Habsbourg afin de soutenir la Pologne. La région de Biélorussie devenait toujours intéressante au moment où cette question était posée encore une fois. La France proposait de faire la confédération des pays baltes en y impliquant le Finnois et même la Pologne, peut-être. En outre, la France faisait la pression afin d'appuyer les indépendances des pays baltes, elle proposait aussi de créer une commission spéciale en motivant ses buts par des menaces réelles d'occuper la région de Ruhr et de Rein.

Malgré les opinions diverses de chaque pays coalisé, le problème principale était toujours la présence des soldats et des volontaires allemands dans les pays baltes, puisque les bolchéviques ne menaçaient directement plus, et donc la question essentielle était d'astreindre mes allemands à quitter cette région. 
En absence des démarches, le Commandement suprême des forces des coalisés a crée une Commission le 10 octobre afin de résoudre la question d'évacuation des allemands des régions baltes, en principe, de le Lituanie et de la Lettonie. Le général d'Italie Marietti participait aussi sur cette Commission.

Larticle présente l'attitude du général Marietti à l'égard du travail de la Commission lors de déménagement de l'armée des volontaires de la Russie occidentale de la région balte ainsi que ses références laissées dans les archives à l'instar d'un observateur impartial. 


\title{
EVACUATION OF GERMANS FROM LITHUANIA IN 1919, THROUGH THE EYES OF THE MEMBER OF INTER CONFEDERATE COMMISSION OF ITALY: OCTOBER-DECEMBER OF 1919
}

\author{
Dr. Ciro PAOLETTI
}

In autumn of 1919, Germans were still in Lithuania and partially in Latvia; gentlemen of Baltics, wanting to preserve their property, supported the Germans, who were still expecting for annexation. Unfortunately, after the defeat Germany could not reveal its purpose of annexation openly, and for this reason used their own established units of colonel P. Bermondt-Avalov, situated in Lithuania and Latvia.

In Paris the Allies were watching this whole situation, but they were disunited as well. USA and Italy did not have any political interest in Baltic region, while at the time France and Great Britain were interested in this. British were seeking to fight against communists the most, as well as for the complete independence of every Baltic country. French wanted the results that would be beneficial for their pursued foreign policy. From the second half of 16th century, by supporting Poland, they wanted to make a lot of trouble to Germany and Habsburg dynasty. When this issue was raised again, Baltic region became indifferent to them. France proposed confederation of Baltic countries, including Finland in it, and maybe even Poland. France was pushing others to support independence of Baltic countries, proposed to establish special commission and based their device by real threats to occupy Ruhr and Rhineland.

Despite different opinions of every country of the Ally, the main problem remained presence of German soldiers and volunteers in Baltic countries because Bolsheviks were not posing direct threat, so the essential issue remains how to force Germans to leave this region.

Seeing that nothing is going on, Supreme leadership of Allied forces found Commission on October the 10th, which was devoted to solve the issue of evacuation of Germans from Baltic countries, mainly from 
Latvia and Lithuania. Italian general Marietti also participated in the work of this commission.

In this article, view of general Marietti, as a neutral observer, is provided about the work of this commission while moving Bermondtists from Baltics, as well as other material that remained in the archives. 